\title{
КОМПЕТЕНТНОСТНЫЙ ПОДХОД В ПОДГОТОВКЕ СПЕЦИАЛИСТА-ПЕДАГОГА В СИСТЕМЕ СПО: ПРОБЛЕМЫ И РЕШЕНИЯ
}

\author{
Батарова Татьяна Михайловна \\ к.П.н., доцент \\ Трифонова Татьяна Сергеевна \\ магистрант \\ АНО ВО «Поволжская академия \\ образования и искусств»
}

\begin{abstract}
Аннотация: в статье рассматривается сущность компетентностного подхода и его специфика в педагогической подготовке специалиста в системе СПО. Авторы дифференцируют понятия «компетенция», «профессиональная компетенция», обозначают ключевые характеристики таких компетенций. В статье рассматривается возможность формирования профессиональных компетенций, отражающих специфику организационно-регулировочных аспектов профессиональной педагогической деятельности посредством внедрения спецкурса.

Ключевые слова: компетенция, профессиональная компетенция, учитель-организатор, организационно-управленческая деятельность, компетентностный подход.
\end{abstract}

\section{COMPETENCE APPROACH IN THE TRAINING OF A TEACHER IN THE SPO SISTEM: PROBLEMS AND SOLUTIONS}

\section{Batarova Tatiana Mikhailovna Trifonofa Tatiana Sergeevna}

\begin{abstract}
: the article examines the essence of the competence approach and its specificity in the pedagogical training of a specialist in the SPO system. The authors differentiate the concepts of "competence", "professional competence", identify the key characteristics of such competencies. The article considers the possibility of forming professional competencies reflecting the specifics of organizational and regulatory aspects of professional pedagogical activity through the introduction of a special course.
\end{abstract}


Key words: competence, professional competence, teacher-manager, organization and managerial activities, competence approach.

Учитель XXI века должен быть готов к осуществлению следующих типов деятельности: педагогической, методической, организационно-управленческой, культурно-просветительской деятельности, то есть быть компетентным специалистом в широком спектре профессиональных сфер и владеть комплексом компетенций.

Общенаучное понятие «компетенция» имеет солидную историю развития и уходит в глубокую древность. Определение данного понятия можно найти, обратившись к словарю. Так, с латинского языка «компетенция соответствовать, подходить».

Сущность и классификации компетенций представлены в многообразии авторских позиций. В качестве комментария представим некоторые из них.

В 50-е годы прошлого столетия американский психолог Р. Кац предложил классификацию компетенций, основываясь на том, что «компетенция есть комплекс знаний, навыков и опыта». Были выделены на основе разных критериев несколько групп компетенций: функциональные компетенции (в аспекте проявления способности к технической экспертизе), управленческие (в контексте планирования, организации и применения ресурсов), коммуникативные (детерминирующие способности эффективного взаимодействия субъектов), концептуальные (отражающие способности предвидеть предстоящие события, планирования на абстрактных уровнях) [4, с. 33-42].

В 70-е годы XX века понятие «компетенция» предстает в том виде, которое используют по сей день благодаря работам С. Craig. В своих трудах ученые Л.М. Спенсер, Р. Бояцис акцентируют внимание на индивидууме, его личных качествах, а также индивидуальном поведение, которые будут влиять на эффективность труда. В частности, Р. Бояцис уточняет, что это такая «способность, проявляющаяся в организации и планировании работы, которая позволит наиболее удачно использовать свои знания и умения в новых ситуациях профессиональной деятельности» [7, с. 23].

В справочной литературе данное определение уточняют С.И. Ожегов, Д.Н. Ушаков. Оба автора отмечают, что компетенция - это некий круг вопросов, в которых человек осведомлен, а также это может быть ряд полномочий [12]. 
С.В. Пучка отмечает, что дискуссии, касающиеся нахождения единого подхода к определению «компетенция» продолжаются. Такие разногласия связаны с тем, что за рубежом термин использовался в сфере бизнеса, когда как в отечественной истории, а также в европейском научном обществе в контексте педагогики и психологии [11].

С точки зрения И.А. Зимней «компетентность - прижизненное формируемое, этносоциокультурное обусловленное, актуализируемое в деятельности, во взаимодействии с другими людьми, основанное на знаниях, интеллектуально и личностно обусловленное интегрированное личностное качество человека, которое, развиваясь в образовательном процессе, становится и его результатом» $[8$, с. 5-10]. А.В. Хуторской дополняет эту мысль, отмечая, что специалисту необходимо, помимо знаниевой составляющей, иметь и личное понимание целевых установок по отношению к основной деятельности, а также обладать опытом взаимодействия в данных условиях. Неким выводом могут служить характеристики сущности категории «компетенция» в контексте профессиональной сферы «человек-человек»: компетенция есть знания, опыт, образовательный стандарт, требования, которые регламентируют деятельность работника для достижения поставленных задач, обусловленные личностным отношением к конкретному труду» [11, с. 23-25]. Данный вывод уместно экстраполировать в педагогическую деятельность, где учитель, как организатор, осуществляет организацию и управление учебной и воспитательной деятельностью. Российский ученый А.В. Хуторской, исследуя область компетентностного подхода в образовании, трактует компетенцию, как «внешнюю норму», предъявляемую социумом в конкретной сфере, а компетентность - владением соответствующей компетенцией (внутреннее качество ученика) [14]. Однако, следует заметить, что данные понимание рассматривается с точки зрения подготовки выпускника школы. Академик уточняет, что профессиональные компетенции следует отличать от образовательных, ведь первые специфичны в назначении, содержании, системе диагностик и оценки [13].

Ученые Европейского Союза, исследуя компетенции, применяют личностный и деятельностный подходы и отмечают, что это «совокупность врожденных или приобретенных личностных характеристик, установок, знаний, навыков, ведущих к качественной работе», а также выявляют различные стороны данного понятия, подразделяя компетенции на характеристики, отношения, знания и навыки, а также определяют широко 
известные ныне «soft skills» или «гибкие навыки», далее выделяя «надпрофессиональные навыки» [5]. Таким образом, наблюдается динамика в разработке характеристик важнейших дефиниций современной педагогической науки - компетентность и компетенция педагога. Дифференцируя понятия «компетенция» и «компетентность», определяют первое: как некую совокупность знаний, умений, навыков, обусловленных личным отношением к процессу деятельности, а второе - как результат такой деятельности.

Обращаясь к трудам А.В. Хуторского, констатируем: получение образования неразрывно связано с жизненным, социальным опытом, которое имеет отражение в применении в практической деятельности.

Современный учитель, ведущий профессиональную деятельность в условиях постоянно усложняющегося информационного пространства, решающий комплексно задачи обучения, развития и воспитания школьников обязан быть компетентным специалистом и владеть набором общекультурных и профессиональных компетенций.

В этом вопросе мы солидарны с мнением Г.М. Коджаспировой, которая считает, что профессиональная компетентность учителя - это «владение учителем необходимой суммой знаний, умений и навыков, определяющих сформированность его педагогической деятельности, педагогического общения и личности учителя как носителя определенных ценностей, идеалов и педагогического сознания» [10, с. 62].

C внедрением ФГОС ВО, направления 44.03.01 Педагогическое образование, подход к оценке освоения программы изменяется. В государственном стандарте обозначены и кодифицированы: универсальные компетенции (УК), общепрофессиональные компетенции (ОПК), профессиональные компетенции (ПК) [3]. Это детерминирует необходимость выстраивать систему подготовки будущих учителей таким образом, чтобы современная парадигма образования была реализована, а также раскрыт управленческий потенциал, который позволит формировать профессиональные компетенции необходимые для освоения позиции учителя-организатора.

Такова картина в системе высшего образования. В системе же СПО в соответствии с ФГОС присутствует иная классификация компетенций: общие и профессиональные компетенции. Профессиональные компетенции будущего учителя являются своеобразным ориентиром для формирования у студентов будущих педагогов - знаний основ учебных предметов, психологопедагогических и дидактических основ методик их преподавания; владения 
способами организации различных форм и видов работы обучающихся в контексте учебного процесса; владения способами регулирования и корректирования индивидуальной, групповой и фронтальной работы. Организационно-управленческий аспект деятельности современного учителя находит отражение в сущностных характеристиках профессиональных компетенций.

Так, например, при подготовке специалистов среднего звена по специальности 44.02.05 «Коррекционная педагогика в начальном образовании» следует учитывать следующие компетенции: ПК 1.2. Планировать и проводить учебные занятия; ПК 1.3. Организовывать учебную деятельность обучающихся, мотивировать их на освоение учебных предметов, курсов; ПК 2.1. Планировать и проводить внеурочные занятия по направлениям развития личности для достижения личностных, метапредметных и предметных образовательных результатов [2]. Реализация указанных профессиональных компетенций предполагает наличие у студентов сформированных коммуникативноуправленческих умений.

Современный выпускник педагогического колледжа с первых дней своей профессиональной деятельности становится организатором учебнопознавательной деятельности обучающихся, регулирует ход учебного процесса, вносит коррективы в поведение и деятельность школьников. С позиции компетентностного подхода он обязан делать это профессионально. Универсальным средством организации и регулирования деятельности школьников является управленческое общение, поэтому коммуникативноуправленческий аспект профессиональных компетенций становится приоритетным в профессиональной подготовке будущего учителя.

Достичь профессиональных вершин можно лишь при условии специально организованной подготовки. На данный момент ни один из учебников педагогики не предоставляет возможность будущим учителям осваивать теоретические и прикладные основы профессиональных компетенций, необходимых для выполнения функций организации и регулирования посредством управленческого общения.

Таким образом, отмечается противоречие между запросом практики по освоению основ управленческого общения как механизма реализации профессиональных компетенций будущего учителя и реальной подготовкой специалиста к выполнению организационной и регулятивной функции педагогической деятельности посредством управленческого общения. Данное 
противоречие может быть преодолено посредством внедрения спецкурса, в основу которого будет положено освоение способов (функций, этапов, приемов) управленческого общения как средства педагогического управления.

Данный факт обусловлен несколькими причинами. Педагогическая деятельность немыслима без непосредственного взаимодействия участников образовательного процесса. Продуктивное взаимодействие возможно при грамотном «использовании» общения, еще В.А. Кан-Калик указывает на неоспоримый факт: «знания наук и методик будут эффективны в педагогической деятельности при использовании системы живого общения» [9, с. 7]. Стадии и функции управленческого общения (по Т.М. Батаровой), безусловно, отражают суть деятельности учителя в профессиональной позиции учителя-организатора и, соответственно, коммуникативно-управленческий аспект его профессиональных компетенций: в умении установить продуктивное взаимодействие, в выдаче организующей и коррекционной информации (информационная функция управленческого общения), в побуждении к сотрудничеству при решении учебных задач (побудительная функция управленческого общения), при осуществлении психологического сопровождения и поддержки отдельных обучающихся посредством коммуникативных средств управленческого общения (функция сопереживания), в обеспечении взаимопонимания, в реализации способностей и учителя, и ученика (функция самоутверждения).

Рассматривая позицию учителя XXI века и анализируя «Профессиональный стандарт» учителя начальных классов, приходим к выводу о том, что такому специалисту необходимо обладать способностью выполнять определенные трудовые действия, а также владеть набором умений и знаний, которые в свою очередь, отражают ничто иное, как парадигму учителяорганизатора на современном этапе образования в России. Так, например, будущему учителю необходимо «организовывать учебный процесс с учетом своеобразия социальной ситуации; корректировать учебную деятельность, исходя из данных мониторинга; проектировать и корректировать индивидуальную образовательную траекторию обучающегося; взаимодействовать с родителями, другими педагогическими работниками, психологами» [1].

К решению этих задач следует целенаправленно готовить будущего педагога на студенческой скамье в рамках спецкурса, формируя 
профессионально значимые коммуникативно-управленческие умения как элементы профессиональных компетенций [6, с. 27-29].

\section{Список литературы}

1. Приказ Министерства образования и науки РФ от 18.10.2013 г. N 544н «Об утверждении профессионального стандарта «Педагог (педагогическая деятельность в сфере дошкольного, начального общего, основного общего, среднего общего образования) (воспитатель, учитель)»

2. Приказ Министерства образования и науки РФ от 13.03.2018 г. N 183 «Об утверждении федерального государственного образовательного стандарта среднего профессионального образования по специальности 44.02 .05 Коррекционная педагогика в начальном образовании»

3. Приказ Министерства образования и науки РФ от 22 февраля 2018 г. N 121 «Об утверждении федерального государственного образовательного стандарта высшего образования - бакалавриат по направлению подготовки 44.03.01 Педагогическое образование» (с изменениями и дополнениями). Редакция с изменениями N 1456 от 26.11.2020

4. Katz, R.L. Skills of an Effective Administrator // Harvard Business Review. 1974. - № 33 (1). - С. 33-42 (дата обращения 09.02.22)

5. Transferability of Skills across Economic Sectors [Электронный ресурс]. - C. 17-22. - Режим доступа: https://clck.ru/bKWF3. (дата обращения: 09.02.2022)

6. Батарова, Т.М. Управленческое общение как средство формирования профессиональных компетенций будущего учителя [Электронный ресурс] / Т.М. Батарова, Т.С. Трифонова // Педагогический форум. - 2021. - № 2 (8). C. 27-29. - Режим доступа: https://clck.ru/bAjyd

7. Бояцис, Р. Компетентный менеджер Модель эффективной работы // M.: HIPPO, 2008. - C. 23.

8. Зимняя, И.А. Компетенция и компетентность в контексте компетентностного подхода в образовании [Электронный ресурс] / И.А. Зимняя // Учёные записки национального общества прикладной лингвистики. 2013. - № 4. - С. 5-10. - Режим доступа: https://clck.ru/ViBn3

9. Кан-Калик, В.А. Учителю о педагогическом общении В.А. Кан-Калик. - М.: Просвещение, 1987. - 190 с.

10. Коджаспирова, Г.М. Педагогический словарь: Для студентов высш. и сред. пед. учеб. Заведений [Электронный ресурс] / Г.М. Коджаспирова, 
А.Ю. Коджаспиров. - М.: Изд. центр «Академия», 2000. - С. 62. - Режим доступа: https://refdb.ru/look/1940555-pall.html (дата обращения: 10.02.22)

11. Пучка, С.В. Компетентностный подход в управлении эффективностью компании: диссертация на соискание ученой степени кандидата экономических наук, Москва, 2019. - 211 с.

12. Словари и энциклопедии [Электронный ресурс]. - Режим доступа: https://endic.ru/ozhegov/Kompetencija-12756.html (дата обращения: 07.02.22)

13. Хуторской, А.В. Компетентностный подход как воплощение договора между социумом и личностью [Электронный ресурс] // Вестник Института образования человека. - 2012. - №2. - С. 2-5. - Режим доступа: http://eidosinstitute.ru/journal/2012/200. (дата обращения: 12.02.22)

14. Хуторской, А.В. Образовательные компетенции и методология дидактики [Электронный ресурс] // А.В. Хуторской. Персональный сайт Хроника бытия; 22.09.2016 г. - Режим доступа: http://khutorskoy.ru/be/2016/0803/ (дата обращения: 09.02.2022)

(C) Т.М. Батарова, Т.С. Трифонова, 2022 